\title{
Challenges and Opportunities for Regional Tourism Development
}

\author{
Milova Yulia Y. \\ Economics and Management Department \\ Irkutsk National Research Technical University \\ Irkutsk, Russia
}

\author{
Piskovets Ekaterina L. \\ Irkutsk National Research Technical University \\ Irkutsk, Russia
}

\author{
Chernyshenko Marina S. \\ Economics and Management Department \\ Irkutsk National Research Technical University \\ Irkutsk, Russia
}

\begin{abstract}
Tourism is playing a more and more important role in the economy of Russian regions. However, not all regions are able to ensure the long-run economic stability. According to the authors, the main causes of regional tourism development problems are drawbacks of the regional tourism management system. The article deals with effects of tourism on regional economies. The authors suggest implementing a number of measures aimed at updating the regional tourism management system. The importance of tourism should not be underestimated. Tourism offerings highlight the value of local and natural attractions, generates economic activity, jobs and export revenues.
\end{abstract}

Keywords - tourism, region, transport, economic development.

\section{INTRODUCTION}

As early as the 1990s, tourism became one of the most dynamic sectors of the world economy. Since the beginning of the XXI century, it has been influencing many national and regional economies. The tourism industry is rather efficient and profitable. Its share in the structure of the global GDP is $12 \%$. The tourism sector employs one out of ten workers. Tourism accounts for $11 \%$ of the total investment. Integration of Russia into the global economic system provides unimpeded access of foreign companies to the market which makes domestic producers gain world market positions. It requires both expertise in tourist excursion activities and abilities to use new advanced tourism management methods.

Growth in popularity and tourist attractiveness of a region and the increase in regional tourist product quality make the regional tourism infrastructure an attractive investment object. Domestic and foreign investment into the regional tourist industry by creating favorable development conditions contributes to a rise in profitability and service quality and promotion of a tourist region domestically and internationally.

Tourism has multiple economic benefits for host countries that receive tourists. Policy makers are becoming more and more aware of the importance that appropriate tourism management has to maximise the benefits that tourism flows can bring. However, many developing countries suffer from a lack of an integrated tourism policy. Particular issues are met in those countries that are dealing with local conflicts (sometimes over many years). These countries often lack investment in tourism resources even though they might have a huge potential and are rich in heritage and cultural assets. Conflict always changes the priorities of nations and poses many challenges to the policy and management for developing tourism as a viable economic sector. Post-conflict areas have barriers to tourism development, such as poor or damaged infrastructure, lack of services, low investment, political instability, a need to maximize revenue income, and the lack of planned tourism management.

The present article analyzes methods for eliminating transport infrastructure development gaps in the tourism industry and managing tourist needs using advanced management tools. Based on the assumption that any infrastructure object can influence the image of a tourist product and become an independent tourist object, the authors argue that proper tourism transport infrastructure management can boost the economic efficiency of tourism transport infrastructure objects, tourism industry and customer satisfaction. For this purpose, it is necessary to develop a complex model of methods (including an object system one), strengthen integration and coordination and set shared goals for tourist and transport companies.

Tourism development strategies require investments in the tourism infrastructure itself, i.e. good road and transportation conditions, access to safe water, control of law and order, provision of trained and motivated work force, availability of efficient banking facilities etc. All these physical and social infrastructure factors, as well as sustainability approaches to business, should be part of a holistic tourism development strategy of a developing country.

Transportation is a crucial component of national economies maintaining them, increasing production 
efficiency, creating conditions for rational location of productive forces (locating plants nearer to raw material sources and consumption areas) [2].

To identify technological features of transport service development with regard to all consumer needs and Russian laws on passenger and baggage transportation, let us study tourism transportation issues.

At present, the Russian tourist transport market is experiencing challenges.

First, transport companies in the tourism sector determine prices for tourist services at their discretion.

Second, in Russia, relationships between tour operators and transport companies have not been properly legislated. The rules of international tourist transport laws are contrary to national laws, which prejudices the rights of Russian tourists. Besides, tourists and employees of tourist and transport companies are not familiar with key international air, sea, river, railway, automobile transportation conventions.

In 2015, tourism contributed $6,5 \%$ to the Russian GDP, and $1 \%$ - to the budget revenues. A share of the global tourist market occupied by Russia is less than $1,5 \%$.

\section{DISCUSSION}

It is obvious that using foreign management experience for managing Russian companies is not only desirable but prerequisite.

Tourism is considered as a crucial social and economic phenomenon. Many nations develop this sector and push ideas and principles of tourism on the global stage. Tourism transport infrastructure is a component of the tourist and transport infrastructure [1].

The government, which was an owner of key transport resources, plays a special role in transport infrastructure development and management. The government is a key investor in transport infrastructure responsible for strategic development of the transport sector as a basis for state security and integrity.

Transport is an essential component of tourism by definition, providing connections between regions, domestically and internationally, and connecting attractions, accommodation and commercial services at destinations. Tourism is a key element in promoting national and regional economies, but it can put pressure on existing transport services and infrastructure. Cities and regions are faced with absorbing seasonal tourist flows while delivering adequate transport network performance.

The location, capacity, efficiency and connectivity of transport can therefore play a significant role in how a destination develops. At the same time, the growing number of travellers creates numerous challenges in terms of transport infrastructure and capacity, border crossing, intermodality, information for travellers and inter-operability of technologies with tourism service providers.

This growth will require close coordination between the different sectors involved in the tourism activities. Making public transport easier to use by tourists and encouraging them to walk or cycle more frequently can help to mitigate negative environmental impacts and manage seasonal peaks. However, the environmental impact of long distance transport remains a significant challenge [12].

\section{A. Tourism transport infrastructure management in foreign} countries

Foreign tourist centers solve transport infrastructure development problems in the tourism industry in a different way. First of all, they pay attention to air transportation, air companies, airports, since most tourists use this transportation mode. In the large and island countries, regional and local airlines play an important role in transporting tourists.

- All transportation modes are well developed and coordinated irrespective of the form of ownership.

- Transport infrastructure objects meet modern comfort and security requirements. most tourists.

- Bilingual information environment is available for

- Developed strategic planning of tourism and transportation activities.

- Up-to-date management of tourism companies and transport operators.

- Marketing support of tourism and transportation sectors.

- Flexible prices for different groups of tourists.

- Developed public transport network.

- Tough transportation and parking regulations and fines.

Restricted transportation in historic city centers, specially protected areas, main transport routes, urban streets (prohibited/limited access): Car Free, Car Sharing, Car Pools.

Except for the above-mentioned factors, new transport infrastructure development projects in tourism are constantly implemented. They are: creating favorable conditions for people travelling by bicycle (creating special paths, expanding the geographical extent of rental centers), environmentallyfriendly transportation promotion, substitution of public vehicles for more advanced ones with gas engines, creating parking areas, free-of-charge transfer between hotels and tourist destinations, free-of-charge use of city passenger transport when staying at city hotels.

Special attention is paid to the projects on reasonable urban growth, new urbanism, transport access management, cargo shipping management, aviation management, speed and traffic restriction, ecological issues [3].

The above-mentioned transport infrastructure management methods are mostly applied by developed countries with welldeveloped transport and tourism infrastructure and a high level of management [9]

Attention should be paid to the Swiss TTI-based touristic product involving interesting tourist itineraries in combination with modern transportation modes and travel cards used for several modes of transport [7]. 
In developing countries, tourism transport management is developing in a different way. It aims at creating transport infrastructure, developing new tourist areas, and tourist attractions. In the UAE and Qatar, the economies are being reoriented from manufacturing to non-manufacturing industries. They are creating airline companies and airports, developing national transit traffic, promoting their countries as tourist destinations.

The Chinese economy, which is the second largest world economy, considers tourism as a growth area and a transport infrastructure - an economic development tool [12].

\section{B. Transport infrastructure management in the Russian} tourism industry

In the age of globalization, transportation development, wide geography of tourism destinations, the Russian tourism sector becomes an inherent component of the global tourism industry. It should use the world's experience to be competitive [4]. The world's experience can be used to solve problems of regional tourism development and to identify key tourism transport infrastructure development areas.

While it is not true to say that the Russian tourism sector has not shown dynamic growth lately, it still trails the world leaders when judged against key indicators for development. The share of tourism in Russia's GDP in 2015 was $6.6 \%$, while the global average was $9.7 \%$. Judging by the number of foreign arrivals per 1,000 people, Russia lags far behind the leading countries. In the UK, for instance, this figure is approximately 525 foreign arrivals per 1,000 people, the world's average stands at 297.8 foreign arrivals, while in Russia, it trails with a mere 161. Employment in Russia in 2015 consisted of $5.6 \%$ in tourism, compared with $10.1 \%$ in the US.

Tourism is closely related to geographical factors and features of regions. To increase competitive advantages of Russia consisting of regions with varied natural, social and economic conditions, it is necessary to analyze tourism development from a regional perspective. Paying attention to the regional tourism development, the tourism attractiveness of the whole country can be improved. At present, despite the interest in regional tourism, the Federal Law "On Basis of Tourist Activities in the Russian Federation", which is a key act regulating tourism in Russia, does not define the concept of regional tourism. Nevertheless, some Russian researchers attempt to define the regional tourism and describe its nature [10]. Regional tourism should be referred to as tourist activities peculiar to a specific region, a set of nations or territories with homogeneous conditions for tourism development and similar level of tourism development. [6].

Tourism as a social category contributes to increasing living standards. In Russia, only few people can afford travelling abroad. Domestic tourism is developing slowly due to deterrents typical for most Russian regions: the lack of government support or failure to perform government responsibilities, transport infrastructure development problems. For example, even the largest Russian recreation region - Caucasian Spas - fails to unlock its potential for tourism development and social welfare remains a beneficiary region. Having all required TTI objects (an international airport, a railway station, a bus station), the region is unable to provide quality services. To identify trouble areas, a detailed analysis of tourism objects is required.

- The Russian regions are facing a dire shortage of good-quality hotel and recreational infrastructure.

- For many regions, transport accessibility to tourism hubs is a problem.

- Low government spending on the sector limits the promotion of tourism facilities as a whole and of particular regions in the global market.

- There is a heavy deficit of qualified personnel able to offer high-quality service to tourists.

- There is no efficient regulatory framework to attract private investments to the sector.

- A lot of regions lack the required environment of entrepreneurship for expanding the tourism sector.

- Among the countries targeting tourism development, Russia's visa rules are the strictest.

Many Russian regions are hardly attractive to investors or tourists because they either have no strategic concept of tourism development whatsoever, or their strategies are simply not well devised and implemented. Regions are given to spontaneously developing areas designated for tourism-related activity. What the regional authorities lack is an understanding of the potential for attracting visitors and their impact on the regional economic development. In many cases, there is no strategy, no feasibility study, nor even a consistent or professionally elaborated plan enabling investors to see just how attractive the region is and the degree of investment risk involved.

Based on the foreign experience, one can say that the main guiding force in TTI management is a government which uses cooperation forms at different budget levels, public and private partnership. Supporting functions are performed by different nonprofit organizations. To convince tourists and residents to use public transport, the governments should make it comfortable, up-to-date, available and free for some categories of residents and tourists. Promotion tools and prohibitive measures should be used as well.

The regional authorities have to implement a range of initiatives for the tourism sector to be able to reach its full potential, thus:

- to ensure that a competitive tourism development concept is in place in the region (many regions of Russia now either have no strategic concept of tourism development whatsoever, or their strategies are not elaborate enough);

- to detect other non-infrastructure problem impeding tourism development in the region (lack of personnel, obstacles to small entrepreneurship expansion, etc.);

- to work out a master plan, a marketing plan and a range of actions to attract private and state investments, ensure that implementation of the selected strategy and tourism development in the region is well managed [13];

- to ensure promotion for the region. 
In 2015, Spain's travel and tourism industry was the biggest in the world. It was followed by Germany, France, the USA, Great Britain, Australia, Italy, Japan, Canada and Singapore. In 2015, they were the leaders in the travel and tourism industry. In 2015, Russia ranked 45th in the world rating improving its performance from its 2013 ranking of 63rd [11].

Travel \& Tourism Competitiveness Index is calculated every two years. The ranking includes 141 countries. In 2017, a new Travel \& Tourism Competitiveness Index will be published.

Table I. Key conditions for regional tourism development*

\begin{tabular}{|l|l|}
\hline Key units & Structural elements \\
\hline Territory and resources & $\begin{array}{l}- \text { regional territory as a tourist } \\
\text { destination; } \\
- \text { natural, geographic, historical, } \\
\text { cultural features and resources of the } \\
\text { territory. } \\
\text { They are the basis of regional tourism } \\
\text { development }\end{array}$ \\
\hline $\begin{array}{l}\text { Social and economic } \\
\text { units }\end{array}$ & $\begin{array}{l}\text { - meeting tourist needs; } \\
\text { - availability of local labor resources; } \\
- \text { availability of information on } \\
\text { developed tourism activities. }\end{array}$ \\
\hline $\begin{array}{l}\text { Organization } \\
\text { management }\end{array}$ & $\begin{array}{l}\text { - regional tourism organization and its } \\
\text { financial support; } \\
\text { - tourism infrastructure development; } \\
\text { - transport accessibility of the region } \\
\text { and its attractions; } \\
\text {-regional tourism development } \\
\text { planning and management; } \\
\text { - tourist safety in the region }\end{array}$ \\
\hline
\end{tabular}

*Made by the authors

\section{RESULTS}

The authors analyzed the level of attractiveness of the Russian regions for foreign tourists. The analysis identified negative aspects of the regional tourism transport infrastructure in Russia.

First, urban, suburban and interurban transportation systems are not designed for foreign tourists. Tickets for different modes of transport are purchased by different booking offices. For foreign tourists, it is difficult to understand how many rides they need, which mode of transport they should use. So they will hardly manage to save on public transport. Russian cashiers who do not speak English are not able to consult them.

Second, European tourists are not accustomed to train delays and lacking bus or tram timetables.

Third, the travel on public transport is not comfortable due to constant traffic jams and road congestion.

Those factors are typical for both Russian cities and towns having less than 100,000 residents. Moreover, some small towns lack public transport, asphalt roads, footpaths and petrol stations.
Even in large Russian cities, there is no night transport. Transport costs are rather high for both Russian residents and foreigners, while transport service quality is rather low. Among the advantages of the Russian transport system, one cam mention safety, reliability, small fines for fare dodging. However, the latter can be hardly referred to the advantages.

Transport infrastructure provides availability of urban areas, regional and national territories, reliability and safety of suburban and interurban transportation, taking into account population mobility and passenger/cargo carriage rising and new environmental regulations [8].

To solve these problems, Russia has to develop a unified transport system which would provide transport intramodality, interaction, complementarity of private and public transport, urban, suburban, and interurban transport systems.

To determine the efficiency of management elements of tourism transport infrastructure and choose an optimal management model, the following evaluation criteria have been developed:

- Revenue per unit area of buildings;

- Revenue per unit area of territories;

- (Mean) revenue per worker;

- Mean number of requests per unit time or system capacity;

- Mean number of busy channels;

- Service denial probability;

- Utility coefficient.

It is recommended to use a tourism transport infrastructure management utility coefficient which can be calculated by dividing a number of tourists by a number of passengers using tourism transport infrastructure management services including transfer passengers (1)

$$
\mathrm{K}=\mathrm{N} / \mathrm{Xn}
$$

where $\mathrm{Xn}$ is the number of passengers using regional TTI services,

$\mathrm{N}$ is the number of tourists in the region.

The coefficient dynamics speaks for efficiency of regional transport infrastructure management. The closer $\mathrm{K}$ to 1 is, the more efficient the regional transport infrastructure management is.

\section{CONCLUSIONS}

The characteristic of tourism transport infrastructure is its non-linearity.

Non-linearity allows us to develop and test system models with realistic dynamic characteristics and form models of various processes.

Simulation modelling is the theory describing the structure and internal relations in the system. The model structure is based on the principles of dynamic behavior of the feedback system, or the model can describe some observed fragments of the system. The model describing process dynamics can 
change paces and levels for transforming system behavior in fulfillment of the task. Simulation modelling is the most promising method for simplified descriptions of real-world processes for the purpose of studying their behavior in different situations.

Human security, including tourists' security, road safety and environmental protection are key issues in TTI management. In view of this, regional tourism transport infrastructure modelling is used to identify its optimal conditions with regard to growing transport and tourist flows, alternatives for transport system development, redistribution of regional traffic flows in order to reduce loads on territories and environment, boost customer satisfaction with tourism and transportation services, attract transfer passengers and tourists to the region.

Efficient regional development of tourism transport infrastructure performs the following tasks:

- Meeting tourist transport demand.

- Providing tourism transportation safety, speed and comfort.

- Rendering the tourist information service.

- Providing an adequate service level.

The key areas of tourism transport infrastructure are as follows:

- Development of modern information systems for traffic regulation and control; restricted traffic and parking areas.

- Development of extensive networks of pedestrian areas, streets, squares, itineraries.

- Development of garaging and parking systems, capacity increase for intercept parking and garages.

Up-to-date transport infrastructure contributes to regional tourism development, social and economic development as it makes social benefits available for people, solves economic tasks of the region, and improve the regional attractiveness for tourists.

\section{The Information Technology Revolution.}

The recent technological developments in the field of communications and information are so far reaching that it is difficult to accurately quantify or describe the distance they put between those who are in possession of the necessary communications infrastructure and technical capacity and those who are not. It is enough to say that tourism is an information industry. Almost everything that connects the market to the destination is a function of information, and the new technologies have already drastically changed how this industry is managed. This presents both challenges and opportunities. A major challenge is that several existing business models are now at risks. Major carriers, tour operators, hotels and travel agents have been thrown into turmoil by the reality that the consumer can reach the product, if he wishes to, without a wall of middlemen in between who while providing a service, increase his costs. He will increasingly evaluate the service against the costs. Consumers can now find the lowest costs for themselves, and, given a chance to create their own packages, they will opt for those components they wish. For those who take comfort from the fact that not everyone is internet savvy or feel comfortable with going on-line both to research information and do business, it is possible to say "Perhaps there will always be those who need to be taken by the hand; the new age and certainly many of our generation will never make the crossing. But surely change is just a generation away" and this points to the role which educators will be playing. How long it takes for the world to be on-line is entirely in the hands of their fraternity [15].

\section{References}

[1] A.Y. Aleksandrova, International tourism, Moscow: Aspect Press, 2005 , $470 \mathrm{p}$.

[2] A.Y. Aleksandrova, International tourism, Moscow: Knorus, 2010, 464 p.

[3] E.F. Akhunzyanova, Efficiency boosting for tourism services with regard to a transport component, Case study of Russian air transportation: Thesis' abstract, Moscow, 2008.

[4] M.B. Birzhakov, V.I. Nikiforov, Tourism industry: transportation, Saint Petersburg: Gerda, 2007, 528 p.

[5] M.B. Birzhakov, Introduction to tourism: Travels. Tourism ad a tourist. Tourist activities. Tourism industry. Tourism product. Tourism services, works, goods, Types of tourism, Laws on tourism, Saint Petersburg: Nevsky fond: Gerda, 2010, 318 p.

[6] B.S. Botasheva, Features of the sanatorium resort structure. Proceedings of the 4th International Scientific Conference of students, post-graduates and young researchers "Research potential of students in the 21th century", Vol. 3, Economics, Stavropol: SevKavSTU, 2010, 592 p.

[7] B.V. Bocharov, Y.E. Machkin, On some factors and features of domestic tourism development in Russia, Works of the International Tourist Academy, Issue 7, Moscow: MTA, 2012, 236 p.

[8] D.Y. Bragin, Interrelation management for tourist and transport companies, Thesis' Abstract, Saint Petersburg, 2002, 17 p.

[9] I.I. Butko, V.A. Sitnikiv, Tourism Transportation, Moscow, Rostov-onDon: MarT, 2006, 335 p.

[10] UN World Tourism Organization. Retrieved from https://www.russiatourism.ru/contents/deyatelnost/mezhdunarodnayadeyatelnost/sotrudnichestvo-v-mezhdunarodnykhorganizatsiyakh/vsemirnaya-turistskaya-organizatsiya-pri-oon-yunvto/

[11] M.Y. Gechebaev, Logistics-based management of the economic system of tourist transport, Thesis, Moscow, 2010, 182 p.

[12] V.N. Glazkov, Tourism service management at railway transport, Moscow: MSRU, 2008, $171 \mathrm{p}$.

[13] A.V. Klyuchnikov, Tourism management. Moscow: Sovetsky sport, 2015, 228 p.

[14] N. Coles, M. C. Hall, International business and tourism: global issues, contemporary interactions, London: Routledge Taylor \& Frances Group, 2008, 283 p.

[15] Holder Jean, Challenges and opportunities facing Caribbean tourism, 2014, 15 p. 